\title{
Optimization of the fermentation time and bacteria cell concentration in the starter culture for cyanide acid removal from wild cassava (Manihot glaziovii)
}

\author{
Mohamed Hawashi ${ }^{1}$, Tika Surya Ningsih ${ }^{1}$, Sekar Bias Tri Cahyani ${ }^{1}$, Kuswandi, Tri Widjaja ${ }^{1}$, and Setiyo Gunawan ${ }^{1, *}$ \\ ${ }^{1}$ Department of Chemical Engineering, Institut Teknologi Sepuluh Nopember, Surabaya 60111, Indonesia
}

\begin{abstract}
Cassava is one of the most widespread starchy tuberous roots in Indonesia, being one of the typical plants used in the starch market. However, due to the high cyanide content (338.41 ppm), these roots become a poison if they are unsuitably processed. Therefore, a detoxification process is needed to reduce the cyanide level to the safe level for human consumption $(10 \mathrm{ppm})$. This study was focused on (i) the investigation of the detoxification potential of fermentation with Lactobacillus plantarum (L. plantarum) on the cyanide level of wild cassava tubers (Manihot glaziovii) and (ii) the optimization of the fermentation time and bacteria cell number in the starter culture. The fermentation was performed for different periods of time $(12,24$ and $36 \mathrm{~h})$ and various initial bacteria cell number $\left(7 \times 10^{10}, 7 \times 10^{11}, 1.05 \times 10^{12}\right.$, and $3.5 \times 10^{12}$ L. plantarum cells). The results showed a significant decrease of the cyanide level, $97 \%$ of cyanide degradation being noticed after $36 \mathrm{~h}$ of fermentation for an initial bacterial cell number of $3.5 \times 10^{12}$ cells. Hence, the strong point of the study consists of a noteworthy reduction of the cyanide content in wild cassava in short periods, whereas the protein content was increased (from $1.5 \%$ to $3.5 \%$ ) in Modified Cassava Flour (MOCAF).
\end{abstract}

\section{Introduction}

Due to its high content in starch, one of the key food sources for humans, cassava (Manihot esculenta) is a raw material to prepare different food products, along with rice, sago, and corn. Cassava plant has several advantages such as high drought tolerance and grown in poor soil, whereas other staple crops are unable to grow under critical conditions of climate and soil [1]. The estimated production of cassava in Indonesia is more than 23 million tons/year [2]. Also, cassava has high productivity, it is easy to cultivate and can provide a good source of food for a vast majority of the Indonesian population and can increase national food security of Indonesia. Although there are more than 100 cassava cultivars in Indonesia, especially on Java Island, only few of them are commonly used. One cultivar that has not been widely used is wild cassava. This cultivar of cassava has a gnarled root system that develops well and has resistance to drought. The analysis of 45 Indonesian cultivars of cassava roots for cyanogenic potential (CP) showed that $\mathrm{CP}$ content usually ranges from 17.8 to $233.2 \mathrm{ppm}$ [3]. The wild cassava roots contain high content of hydrocyanic acid (HCN) ranges from 183.2$357.2 \mathrm{mg} / \mathrm{kg}$ on dry matter basis (DM) [4]. Its flavor is influenced by the amount of cyanogenic glucosides present in roots, which make it bitter. However, cassava root has a high starch content, which makes it a good source for starch processing with applications in food industry[5]. Generally, starch contains 15-30\% amylose and $70-85 \%$ amylopectin [6]. Amylose has a strong effect on starch, while amylopectin provides crisp effects in food [7].The utilization of wild cassava root as such for food purposes has few drawbacks, because it contains high toxic cyanogenic glucosides compounds (93\% linamarin and 7\% lotaustralin) [8]. Cassava roots also contain the enzyme linamarase, which can hydrolyze linamarin to produce glucose and acetone cyanohydrin. Furthermore, it can also decompose to acetone and $\mathrm{HCN}$ spontaneously at $\mathrm{pH}$ higher than 4 and temperatures greater than $30^{\circ} \mathrm{C}$ [9], as shown in Figure 1 .

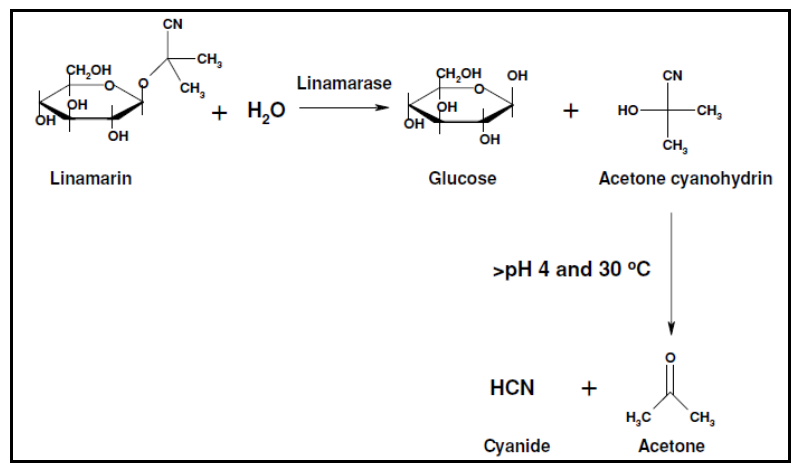

Fig.1 Enzymatic breakdown of the major cyanogenic glucosides (linamarin) in cassava roots [9]. 
Hydrocyanic acid is a highly toxic compound for humans. Therefore, the toxic potential of cassava roots should be addressed during cassava root processing before human consumption. The roots have to be detoxified to less than $10 \mathrm{ppm}$, which is the safe limit proposed by the World Health Organization [10]. The lactic acid fermentation is one of the most used processes for cassava detoxification during the fermentation process the formation of lactic acid decreases the $\mathrm{pH}$ below 6 . This causes the laminarase enzyme to become non-active, and linamarin does not change into HCN. L. plantarum is a lactic acid bacteria commonly used in the fermentation process. These bacteria have antagonistic properties against fooddamaging microorganisms, such as Staphylococcus aureus and Salmonella. L. plantarum is tolerant to salt, produces acid quickly and has an optimum $\mathrm{pH}$ of 5.3-5.6 [11]. Nevertheless, although the fermentation process is widely used, there is a lack of information about optimal parameters, in particular the fermentation time and bacteria concentration, to carry out the process.

Therefore, the objective of this study was to evaluate the effect of the bacteria concentration in the starter culture on the cyanide removal in wild cassava for the production of cassava flour. The fermentation time was also investigated in order to optimize the detoxification process of the roots. The fermentation was performed by a submerged process with the addition of $L$. plantarum bacteria.

\section{Materials and methods}

\subsection{Materials}

Wild cassava roots were obtained from a cassava plantation in Blitar, which is located in East Java, Indonesia. The L. plantarum bacteria was obtained from the "Chemical Laboratory of Microbiology" of Chemical Engineering Department, Institut Teknologi Sepuluh Nopember (ITS) Surabaya.

\subsection{Sample and preparation}

Freshly harvested cassava roots were chosen so that to keep the normal level of the proximate content. Cassava roots were peeled out and the skin was washed with running water at $28{ }^{\circ} \mathrm{C}$. After that, the proximate composition of wild cassava was performed. Furthermore, wild cassava was cut into chip form with a thickness of $0.5-1 \mathrm{~cm}$ to increase the surface area.

\subsection{Production of MOCAF}

\subsubsection{Preparation of starter bacteria (L. plantarum)}

The $L$.plantarum inoculum was prepared in an Erlenmeyer flask containing $15 \mathrm{ml}$ of nutrient broth (NB), and $135 \mathrm{~mL}$ of distilled water. The mixture was incubated for $16 \mathrm{~h}$ to achieve bacterial growth in $\log$ phase. The starter volume used for fermentation was adjusted by the variable number of $L$. plantarum bacteria cells. All the tools used for experiments were sterilized previously. The sterilization was carried out in an autoclave at $121^{\circ} \mathrm{C}$ for $15 \mathrm{~min}$.

\subsubsection{Fermentation process}

A $150 \mathrm{~g}$ of cassava roots were used for the fermentation process. The starter amount of $L$. plantarum cells of $7 \times 10^{10}, 7 \times 10^{11}, 1.05 \times 10^{12}$ and $3.5 \times 10^{12}$ were added. The fermentation was performed for 12, 24 and $36 \mathrm{~h}$. The temperature was kept constant at $32{ }^{\circ} \mathrm{C}$ during fermentation.

\subsubsection{Milling process}

After fermentation, cassava roots were dried in oven at $45^{\circ} \mathrm{C}$ for $4 \mathrm{~h}$, and then milled in a crusher. After milling, cassava flour was sieved to obtain a granulometric fraction lower than 100 mesh. The resulted flour was denoted as (MOCAF)

\subsection{Determination of proximate composition}

The proximate composition of wild cassava variety was determined for moisture, ash, crude fiber, fat and protein content as described by Association of Official Analytical Chemist (AOAC) [12].

\subsection{Determination of cyanide content}

The cyanide acid content on fresh and fermented cassava roots was determined as described by [13]. $20 \mathrm{~g}$ of sample were transferred into a Kjeldahl digestion flask. Then, $200 \mathrm{~mL}$ of distilled water was added to the digestion flask. The flask was stirred to mix the content thoroughly for $2 \mathrm{~h}$, then placed on the heater to recover cyanide acid as distillate. The distillate was collected in a conical flask containing $20 \mathrm{~mL}$ of $2.5 \% \mathrm{NaOH}$ solution. Next, $8 \mathrm{~mL}$ of $\mathrm{NH}_{4} \mathrm{OH}$ solution and $5 \mathrm{~mL}$ of $5 \% \mathrm{KI}$ solution were added as an indicator. The resulting mixture was titrated against $0.02 \mathrm{~N} \mathrm{AgNO}_{3}$ until there was turbidity. A blank was also run through all steps above. The cyanide acid content was calculated from the amount of $\mathrm{AgNO}_{3}$ used for titration.

$\mathrm{HCN}(\mathrm{mg} / \mathrm{kg})=\frac{\left(\mathrm{V}_{1}-\mathrm{V}_{2}\right) \times \mathrm{N} \times 27}{\left(\mathrm{~V}_{3} \times \mathrm{W}\right)}$

Where $\mathrm{V} 1, \mathrm{~V} 2, \mathrm{~V} 3, \mathrm{~N}$, and $\mathrm{W}$ are the blank titration volume, sample titration volume, distillate volume, $\mathrm{AgNO}_{3}$ normality, and sample weight, respectively.

\subsection{Determination of Starch Content}

The starch content of the cassava sample was determined as described by [12]. A $2 \mathrm{~g}$ of sample was immersed into $50 \mathrm{~mL}$ of distilled water and stirred for $1 \mathrm{~h}$ on a magnetic stirrer. Next, the solids were separated by filtration and washed with distilled water to produce 250 
$\mathrm{mL}$ of filtrate, while the residue left on filter paper was washed with $10 \mathrm{~mL}$ diethyl ether and then with $150 \mathrm{~mL}$ of $10 \%$ ethanol. Then, the solid was transferred to an Erlenmeyer flask and cleaned with $200 \mathrm{~mL}$ of distilled water. $20 \mathrm{~mL}$ of $\mathrm{HCl}$ was added and the mixture was heated above its boiling point for $2.5 \mathrm{~h}$. After cooling, the sample was neutralized with $500 \mathrm{ml}$ of $45 \% \mathrm{NaOH}$ solution and filtered through Whatman paper. Furthermore, the sugar content of the filtrate was analyzed using the Nelson-Somogyi method. From these methods, the glucose content was obtained, and the percentage of starch was determined by multiplying the glucose content by 0.9 (factor number).

\section{Results and discussion}

\subsection{Chemical composition of fresh wild cassava root}

According to the proximate composition, the wild cassava used for this study contains $81.57 \%$ starch, 1.25 $\%$ protein, $0.39 \%$ lipids, $1.28 \%$ fibers, $0.26 \%$ ash, and $13,74 \%$ moisture. The cyanide acid content of fresh cassava was $338.41 \mathrm{ppm}$. These results clearly shows that the cassava roots used for this investigation are promising raw materials for starch production but the high content of the cyanide limits its exploitation. Therefore, detoxification process of these roots is a mandatory step before utilization in food industry.

\subsection{Microbial growth}

The fermentation process was performed by using of $L$. plantarum bacteria. To determine the time necessary to reach the log phase of $L$. plantarum, the growth curve was obtained. The calibration of the growth curve of microorganisms was performed using the counting chamber method, which aims to determine the number of microorganisms used in fermentation. Calculation of cell count was made every $2 \mathrm{~h}$ for $24 \mathrm{~h}$. The logarithmic phase of the $L$. plantarum growth curve was obtained from 6 to $16 \mathrm{~h}$ (Figure 2). This log phase was used to determine the amount of bacteria by using the number of different starter volumes on each variable of the number of microorganisms.

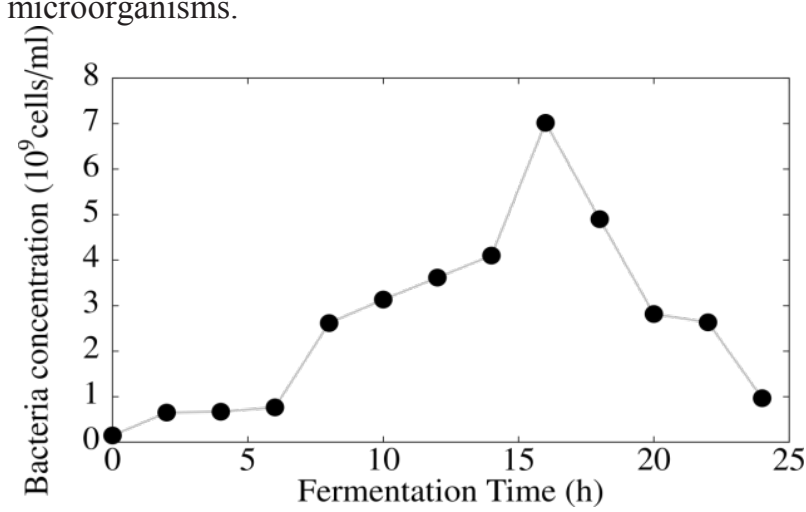

Fig.2. Growth curve of bacteria L. plantarum

\subsection{Effect of the starter culture concentration on wild cassava fermentation}

Two types of fermentation are used for processing of cassava roots, spontaneous and the starter culture, both of them are commonly used in Central Africa and Asia [9]. In this study, fermentation with starter cultures on wild cassava roots was used with the number of microorganisms being increased from $7 \times 10^{10}, 7 \times 10^{11}$, $1.05 \times 10^{12}$, to $3.5 \times 10^{12}$ L. plantarum cells with a fermentation time of 12,24 and $36 \mathrm{~h}$.

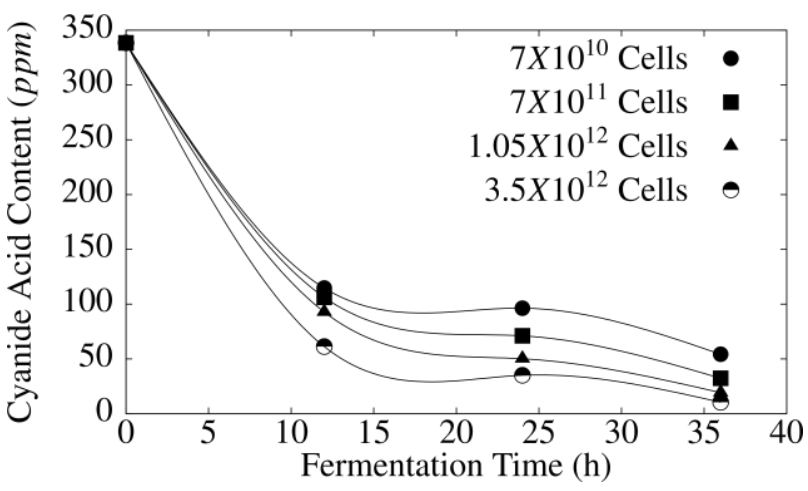

Fig.3. Effect of initial bacteria cell number on cyanide acid $(\mathrm{HCN})$ removal in cassava roots fermentation.

Figure 3 shows that higher concentration of $L$. plantarum cells and longer fermentation periods have a positive effect on the HCN content in cassava. The decrease in $\mathrm{HCN}$ levels occurs drastically from $\sim 350$ to $\sim 50 \mathrm{ppm}$ in the first $12 \mathrm{~h}$ of fermentation. After $36 \mathrm{~h}$ of fermentation and using a concentration of $3.5 \times 10^{12}$ cells, the cyanide content was further decreased up to 10.44 ppm. This remarkable fall could be explained by the enzymatic activity during fermentation, when the $\mathrm{pH}$ is lowered at 4 , a value at which the enzymatic activity of linamarase, whose optimum $\mathrm{pH}$ is 6 , is drastically reduced [14]. Due to the fact that linamarin and $\mathrm{HCN}$ are very soluble in water, the submerged fermentation process will provide the best conditions for the enzymatic activity aiming to reduce the HCN content in the wild cassava tuber. It is important to mention that a starter culture containing $3.5 \times 10^{12}$ cells decreases the cyanide content up to $94 \%$ in the first $24 \mathrm{~h}$, value that is superior to $91 \%$ obtained for mixed-starter culture [15]. In the light of this result, the advantage of pure culture such an L. plantarum is reproducibility and control to produce MOCAF with low cyanide content.

\subsection{Effect of the starter culture concentration on the starch content}

Starch is composed of two glucose polymers, i.e., amylose and amylopectin. Amylose is a linear $\alpha-(1 \rightarrow 4)$ glucose polymer, while the amylopectin consists of short linear $\alpha-(1 \rightarrow 4)$ linked chains with $\alpha-(1 \rightarrow 6)$ linked side chains [16]. The mass ratio between these two components is around 1:3. However, from the medical point of view, a starch with higher content in amylose is 
preferred (the so-called "resistant starch") because it has a good effect on the physiological function of the body, due to its hypoglycemic effect (lowers blood sugar after meals), prebiotic effect, it lowers cholesterol and reduces the risk of colon cancer [6]. Thus, there is a huge interest to prepare such kind of starch. Our study shows that it is feasible to regulate the ratio between amylose and amylopectine in starch by controlling the concentration of the L. plantarum cells in the starter culture.

Figure 4 shows the evolution of the starch content over time depending on the concentration of microorganisms during cassava fermentation, when a decrease in the starch content with the increase of fermentation time and cell concentration was observed.

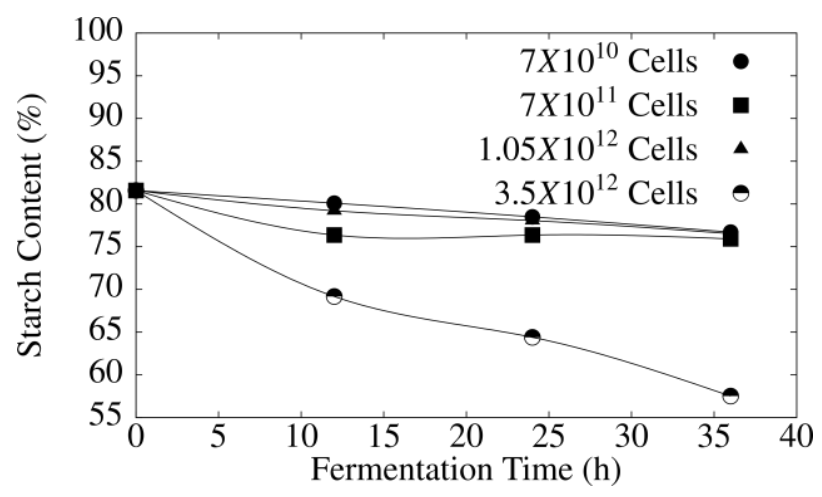

Fig.4. Effect of initial bacteria cell number on starch content.

A dramatic decay was noticed for a concentration of $3.5 \times 10^{12}$ cells. The decrease in starch content is caused by the use of organic matter to meet the energy needs for the growth of microorganisms [6]. It is well known that during the process of fermentation, the starch is hydrolyzed into simpler sugars from oligosaccharides and maltose to glucose [11].

The effect of the cells concentration on the evolution of the amylose and amylopectin content during the fermentation process is depicted in Figures 5 and 6 , respectively. It can be noticed that a value of $3.5 \times 10^{12}$ cells was the optimum concentration at which the content of starch components were changed over time in the favour of amylase. These results were in accordance with previous studies [17]. Cassava roots were allowed to ferment enough time to reach an acidic $\mathrm{pH}$ value (put the value of $\mathrm{pH}$ ), as a result of bacterial activity, suitable to start the starch hydrolysis at $\alpha$ - (1.4) bonds, thus increasing amylose groups [6]. According to Syahputri et al, a similar behavior was observed in the amylose content of fermented jali flour, for which the amylose content increased from $26.33 \%$ to $29.06 \%$ [18]. Enhance of the amylose content is justified by the breaking of the amylopectin branch chain at $\alpha$ - (1.6) glycoside bonds as a result of enzyme activity during fermentation.

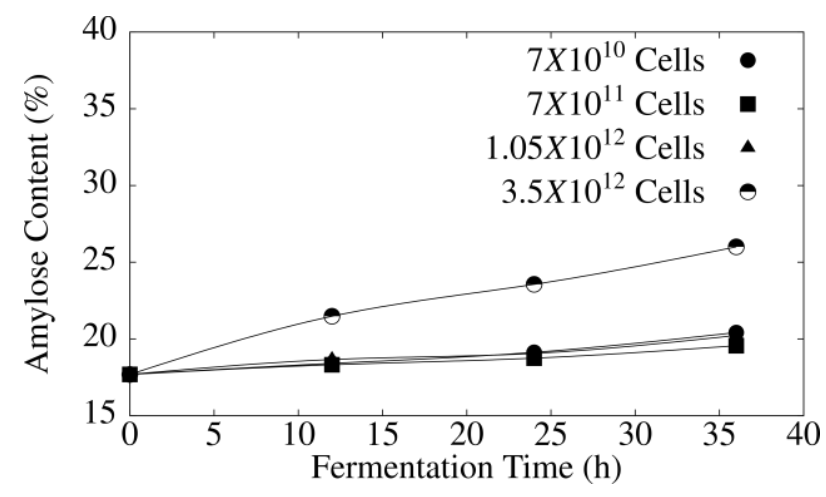

Fig.5. Effect of initial bacteria cell number on amylose content during cassava fermentation.

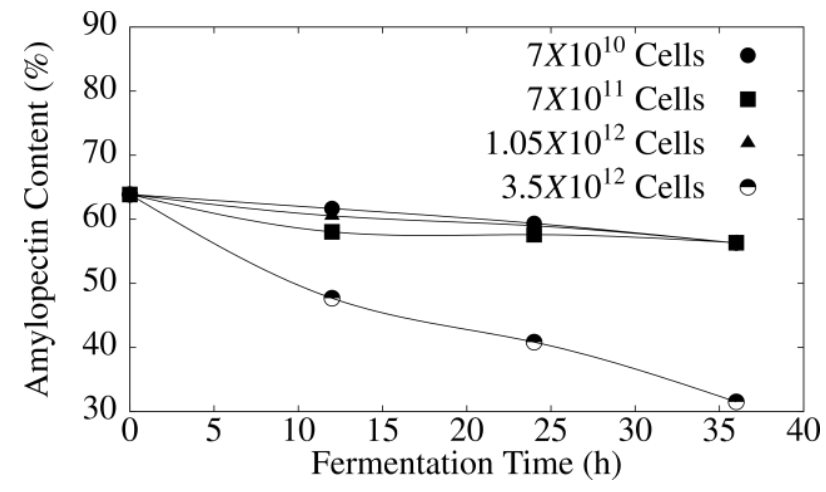

Fig.6. Effect of bacteria concentration on amylopectin content during cassava fermentation.

The highest amount of amylose (26\%) was obtained of fermentation $(36 \mathrm{~h})$ for the higher bacteria concentration $\left(3.5 \times 10^{12}\right.$ cells $)$. As already mention above and according to Aliawati indicated that high amylose content correlates with high resistant starch [19]. Therefore, the product generated by our work has the potential to be used as raw material for resistant starch.

\subsection{Effect of the starter culture concentration on the protein content}

The current study was mainly focused on the detoxification of the cassava roots. The protein content was also evaluated, since high protein content in MOCAF is essential for nutritional reasons. It was interesting to emphasize that an increase in the protein concentration was noticed for the highest concentration of the cells in the starter culture. This feature is of particular interest knowing that usually, the protein content in MOCAF is improved by adding powdered dried fish debris, oil cake, or soybean flour to the cassava flour [20].The results are illustrated in Figure 7. 


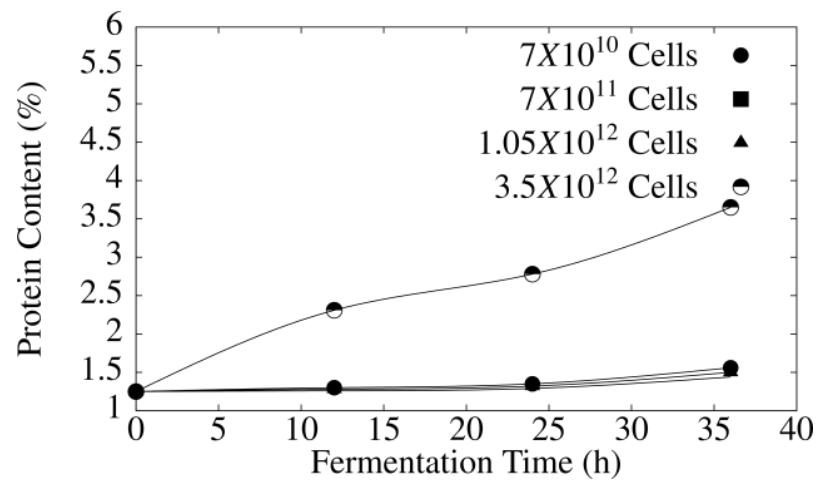

Fig.7. Effect of initial bacteria cell number on protein content during cassava fermentation.

Accordingly, the protein content was below $1.5 \%$ after $36 \mathrm{~h}$ of fermentation regardless the concentration of the cells up to a value of $3.5 \times 10^{12}$ cells. Once the concentration of the cells reached this limit value, a continuous increase of the protein content was noticed right from the beginning of the fermentation process that reached a value of $3.5 \%$ after $36 \mathrm{~h}$ of fermentation. This percentage is similar with those reported by other authors in different cassava fermentation $4.07 \%$ and $2.19 \%$ for $48 \mathrm{~h}[14,21]$. However, in the present study, a shorter fermentation time was required. It is important to mention that higher protein content in MOCAF is essential for nutrimental reasons. However this is not easy to achieve; in consequence, the supplementation with soybean powders has been suggested by other authors. The present work is focused on the degradation of cyanide in the shorter possible time, but protein content is also an important matter to take into consideration for further studies.

\section{Conclusions}

This study showed an L. plantarum high-performance fermentation process to decrease the cyanide acid content of cassava roots. The toxicity of the roots significantly decreased under optimized conditions concerning the initial bacteria cell number in the starter culture $\left(3.5 \times 10^{12}\right.$ cells $)$ and fermentation time $(36 \mathrm{~h})$. Additionally, an improvement of the protein content in the cassava flour was obtained under optimized fermentation conditions. Therefore, we are confident that the outputs of this work open new ways as concerns the cyanide removal in cassava roots and the enhancement of protein content of MOCAF in a controlled and reproducible manner.

\section{References}

1.S. Gunawan, Z. Istighfarah, H. W. Aparamarta, F. Syarifah, I. Dwitasari. Handbook on Cassava. Nova Science Publishers, Inc., New York, 271295 (2017)

2. Food and Agriculture Organization (FAO). Food Outlook: Binnual Report on Global Food Market. Italy (2015)
3. A. Hidayat, N. Zuraida, I. Hanarida. Indones. J. Agric. Sci. 3, 25-32 (2002)

4.N.M.A. Nassar. Genet. Mol. Biol. 23, 201-212 (2000)

5.FAO and IFAD international fund for agricultural development food and agriculture organization of the united nations. The world cassava economy. Rome, (2000)

6. M.G. Sajilata, S.S. Rekha, R.K. Puspha. Compr. Rev. Food. Sci. Food Saf. 5, 1-17 (2006)

7. Shu X, Jia L, Gao J, Song Y, Zhao H, Nakamura Y, Wu D. Starch, 59, 504-509 (2007)

8. Winarno. Kimia Pangan dan Gizi. Gramedia Pustaka Utama, Jakarta (1992)

9. J.A. Montagnac, C.R. Davis, S.A. Tanumihardjo. Compr. Rev. Food. Sci. Food Saf. 8, 17-27 (2009)

10. World Health Organization (WHO). Aldicarb. Environmental Health Criteria No. 121. International Programme on Chemical Safety (1991)

11. K.A. Buckle, R.A. Edwards, G.H. Fleet, M. Wooton. Ilmu Pangan. Universitas Indonesia Press. Jakarta, (1985)

12. AOAC International. Official methods of analysis of AOAC International. 17th edition. 2nd revision. Association of Analytical Communities, Gaithersburg (2003)

13. SNI standard. Modified cassava flour. SNI 7622. National Standardization Agency of Indonesia, Jakarta (2011)

14. S. Gunawan, T. Widjaja, S. Zullaikah, L. Ernawati, N. Istianah. Int. Food Res. J. 22,12801287 (2015)

15. N.Z Nkoudou, J.J.N Essia, Food Nutr. Sci. 8,326-333 (2017)

16. M.J.E.C. van der Maarel, B. van der Veen, J.C.M. Uitdehaag, H. Leemhuis, L. Dijkhuizen. J. Biotechnol., 94, 137-155 (2002)

17. A.L. Lehninger, D.L. Nelson, M.M. Cox. Principles of Biochemistry. Worth Publish, New York (1982)

18. D.A. Syahputri, A.K. Wardani. J. Pangan Agroindustri, 3 984-995 (2015)

19. G. Aliawati. Teknik analisis kadar amilosa dalam beras. Buletin Teknik Pertanian. 8, 82-84 (2003)

20. National Research Council (US) Applications of Biotechnology to Fermented Foods: Report of an Ad Hoc Panel of the Board on Science and Technology for International Development. National Academies Press, Washington DC (1992)

21. J. Sulistyo, L.J. Shya, H. Mamat, N.A. Wahab. AIP Conf. Proc. 1744, 020030-1-020030-9 (2016). 